Sara Brezigar

\title{
CRITICAL REFLECTIONS ON MANAGING CULTURAL DIVERSITY IN WORKPLACES IN SLOVENIA
}

\begin{abstract}
The paper focuses on managing cultural diversity at workplaces in Slovenia. The author critically reflects on some aspects of research and studies that have been carried out both on discrimination as well as managing diversity in Slovenia between 2007 and 2013, and finds the cause of the inability of organisations to adopt policies on managing diversity in the lack of competences and skills associated with cultural sensibility. The author maintains that whereas workplaces are bound to become more and more diverse, the predominant approach towards diversity in workplaces in Slovenia tends to either dismiss (cultural) diversity as inconsequential or treat it as a nuisance that needs to be dealt with, thus failing to grasp the advantages which such diversity could bring.
\end{abstract}

Keywords: workplace diversity, managing diversity, workplace, Slovenia, cultural diversity

\section{KRITIČNI POGLED NA UPRAVLJANJE KULTURNE RAZLIČNOSTI V DELOV- NIH OKOLJIH V SLOVENIJI - POVZETEK}

Članek obravnava upravljanje kulturne različnosti v delovnih okoljih v Sloveniji. Avtorica kritično oceni nekatere vidike raziskav in študij o diskriminaciji in upravljanju različnosti v Sloveniji med letoma 2007 in 2013; nezmožnost organizacij, da bi uporabile politike upravljanja različnosti, pri tem pojasni s pomanjkanjem kompetenc in veščin, ki so povezane z delovanjem v večkulturnem okolju. Medtem ko postajajo delovna okolja vse bolj raznolika, v slovenskih delovnih okoljih bodisi zavračamo kulturno raznolikost kot nepomembno bodisi jo obravnavamo kot nadlogo, s katero se je treba ukvarjati, pri tem pa ne dojamemo prednosti, ki jih takšna raznolikost ponuja.

Ključne besede: različnost v delovnem okolju, upravljanje različnosti, delovno okolje, Slovenija, kulturna različnost

Sara Brezigar, Associate Professor, Faculty of Education at the University of Primorska, The Institute for Ethnic Studies, sara.brezigar@inv.si 


\section{INTRODUCTION}

In the past decades there has been an increasing interest in the study of ethnic minorities and immigrants (Brezigar, 2007a; Komac and Medvešek, 2005; Komac, 2007; Bešter, 2007; Pajnik, Bajt and Herič, 2010; Golja, 2007, 2008; Medica, Lukič and Bufon, 2010; Bešter and Medvešek, 2010), and special attention was devoted to their situation in the labour market (Pajnik et al., 2010; Brezigar, 2010; Medica, 2010). These studies mostly focus on the experiences of immigrants and ethnic minority members, their integration into Slovenian society and the discrimination which they may face. However, little attention has been paid so far to how racial, ethnic, religious, linguistic - or in one word cultural - diversity of the population impacts workplaces in Slovenia and how organisations respond to it. Do organisatons take advantage of this kind of diversity and do they adapt to it? Are they making any effort to capitalise on it? Or are they treating it as a nuisance, neglecting it or even denying its existence?

The aim of this paper is to reflect on how cultural diversity is perceived and managed in workplaces in Slovenia and to provide an insight into the topic that could serve as a starting point for a future comprehensive study.

Since no comprehensive studies have been carried out on the topic in Slovenia so far, ${ }^{1}$ the paper will draw on data from studies on integration and discrimination of ethnic minorities and immigrants between 2007 and $2013,{ }^{2}$ and will try to explain how cultural diversity in workplaces is frequently not perceived as an asset in Slovenia, and how the lack of skills may contribute to this situation.

The first part of the paper focuses on the concept of managing cultural diversity. It includes explanation of how the concept of »culture« relates to workplace and how »managing diversity policies « differ from other type of policies. The second part of the paper attempts at a tentative explanation of the status quo regarding the use of diversity managing policies in workplaces in Slovenia, pointing out the role (and absence) of adequate training. I will now proceed to explore the concept of culture in workplaces.

\footnotetext{
1 In the past decade, two interesting studies have been carried out in Slovenia, alongside the mostly practical work of Tatjana Greif $(2009,2009 a)$ : one on discrimination in the labour market (Dolenc, 2011) and one on managing diversity in companies (Kosi, Nastav and Dolenc, 2012). However, these deal with religious, ethnic, national and racial diversity very superficially and provide little data that could explain the status quo regarding managing cultural diversity in companies.

2 Data used in this paper has been collected and analysed as part of the following projects: a PhD dissertation on ethnic discrimination in the public service, police and army in Slovenia (Brezigar, 2007a), a study on the integration of third country nationals in Slovenia (Bešter and Medvešek, 2010), and two country reports on Slovenia: one on the grounds of religion or belief (Brezigar, 2012) and one on the economic case for antidiscrimination (Brezigar, 2011).
} 


\section{"CULTURAL« DIVERSITY IN WORKPLACES}

To understand the meaning and role of culture in a workplace context, one must focus on two main characteristics of culture: firstly, culture is learnt, and secondly, culture is shared.

The first characteristic means that the way we think, feel and act is largely impacted by the context in which we live, the values and assumptions that we internalise, the behaviours that we learn.

The second characteristics means that culture consist of behaviours, values, assumptions and according to some scholars (Giddens, 2002; Farley, 1990; Latour, 1993) even material objects of a social group or society as a whole. ${ }^{3}$

During the course of our lives, we are exposed to many different cultures. Some of them are more general, whereas others are more specific. We usually start as rookies and then proceed to learn, or as Haralambos, Holborn and Robin (2006, p. 3) put it: »The infant has a lot to learn. In order to survive, it must learn the skills, knowledge and accepted ways of behaving of the society into which it is born«.

When we apply the concept of culture to workplaces, we encounter an interaction of different cultures:

Firstly, there is the national culture which is strongly linked with language and nationality (or ethnic and racial affiliation). ${ }^{4}$ The national culture represents a common ground, a »context« culture of the company and its employees: something they share, something that puts them on the same wavelength (cf. Trompenaars and Hampden-Turner, 2012). However, when employees have different nationalities and/or the company is not a local micro enterprise, but rather a multinational company with branches in several countries, then national culture ceases to be a common ground for »thinking and acting «, and becomes a source of differing views, approaches, values and priorities that need to be addressed in the board room.

Researchers (Bartels, 1967; Hofstede, 19805; Trompenaars and Hampden-Turner, 2012) have carried out extensive study of the differences among national cultures in an attempt to create a framework that would help companies to overcome cultural clashes, avoid problems with international mergers and learn how to run an international company and manage a culturally diverse workforce.

Secondly, there is the corporate or organisational culture (Deal and Kennedy, 2000, 2008; Schein, 2010). According to the Collins English Dictionary corporate culture is

3 For example, Giddens (2002, p. 22) believes that culture comprises both intangible aspects of life, e.g. beliefs, ideas and values, which form the content of culture. These are accompanied by the tangible aspects like objects, symbols or technology, which represent that content (Giddens, 2002, p. 22).

4 This is particularly true in the case of nation-states.

5 Cf. with Jones 2007; McSweeney, 2002; Schwartz, 1994; Hofstede, 2002. 
the »distinctive ethos of an organization that influences the level of formality, loyalty, and general behaviour of its employees«. Corporate culture consists of an organization's knowledge and history that is cultivated by it over a period of time and results in commonly held values, norms, customs, paradigms and worldviews shared by the members of the organization. It guides new employees when integrating into the organization and interacting with organization's outside environment. Frequently, it is conceived as a managerial tool (Trompenaars and Hampden-Turner, 2012; Schein, 2010), though sometimes it has been proven as difficult to manage and impervious to change.

Apart from the two types mentioned above, Hogan (2002) identifies two more types of culture in workplaces: firstly, professional culture that is best understood if we compare how an average accountant, salesman and IT engineer differ from one another. Professional culture is usually highly linked with one's profession - therefore with education and the standards, values, behaviours that each profession fosters (Bloo, 1994).

And secondly, Hogan (2002) also introduces generational culture that differs according to one's age - or, more accurately, it depends on when one was born. The values, beliefs, attitudes are shaped by time and therefore different generations tend to have a different attitude towards work, their employer, co-workers, company, work-life balance, career, etc.

In contrast with Hogan's broader view of culture, according to which any diversity in workplace is perceived as cultural, Trompenaars and Hampden-Turner (2012) identify $»$ cultural« diversity as primarily related to national culture. According to them, corporate culture is a management tool that should take into account the »cultural « diversity related to national culture, whereas the rest is left to a chapter on »diversity of diversity « (Trompenaars and Hampden-Turner, 2012, p. 301) that includes gender, age, functional diversity, etc.

While acknowledging the multitude of views on cultural diversity, this paper chooses to adopt a limited view on cultural diversity - one that encompasses religion, ethnicity, nationality, race (and possibly language) and is as such more in line with Trompenaars' than Hogans' concept. In this paper I will therefore confine myself to those aspects of cultural diversity (hereinafter referred to as diversity), that are mostly related to ethnicity and religion, while leaving gender, age and intergenerational issues aside. I will now proceed to clarify what it means to »manage« diversity in a workplace environment.

\section{MANAGING DIVERSITY POLICIES}

How managing diversity works and what it stands for is best understood if we compare it with other types of policies aimed at dealing with cultural diversity in workplaces.

Policies dealing with cultural diversity can broadly be grouped into three groups: equal opportunities policies, positive discrimination policies and diversity management policies. All three types of policies deal with cultural diversity, but their approaches differ immensely. 
Equal opportunity policies are based on the principles of equality and non-discrimination and their aim is the full implementation of these principles. Positive discrimination policies represent unequal, preferential treatment of persons belonging to ethnic (religious, racial, national) groups that are in a weaker social position. Diversity management policies are based on the recognition of the diversity of the workforce and the creation of specific, tailored policies for different (groups of) employees (Mavin and Girling, 2000). The three sets of policies differ in two fundamental dimensions: the social level on which they are conceived, and the principles of justice upon which they are based (Brezigar, 2007b).

Equal opportunity policies usually stem from formal, legal requirements regarding equal treatment and non-discrimination that have been agreed upon at national or supranational level and also need to be implemented at the organisational level. In Slovenia, a number of legal acts require employers to treat employees equally and refrain from discrimination (Brezigar, 2007a; Bešter and Medvešek, 2010).

Similarly, positive discrimination policies are adopted by organisations on the basis of a legal or formal requirement that has usually been adopted at regional, national or international level. In Slovenia, positive discrimination policies are found primarily in the treatment of autochthonous minorities or are established for certain domains or certain ethnic groups (e.g. Roma). Employers, however, are not widely required to implement these kind of policies in their organisations. ${ }^{6}$

In contrast, diversity management policies are usually not directly related to the legal regulation in the field of employment, which prohibits various forms of discrimination in the workplace. In essence, the philosophy of managing diversity is voluntary and requires individual organizations to undertake the necessary steps to deal with external demographic trends. Thus, the onus of achieving diversity in the workplace is on the shoulders of organisations and their managers.

Diversity managing policies differ from equal opportunities policies, since the latter pursue the objective of treating all employees equally - therefore making ethnicity, race or religion irrelevant in the workplace. In contrast, diversity managing policies encourage organizations to recognize differences between different ethnic groups (Liff, 1997, p. 13). This approach is based on the belief that it is necessary to recognize the existence of differences and adapt to them, rather than - as equal opportunities policies do - pretend that such differences do not exist (Liff, 1997, p.13).

Trompenaars and Hampden-Turner (2012, p. 364) proposed a framework to manage diversity in workplaces known as the 4 Rs:

- The 1st R stands for recognition and explores what is the level of one's competence in recognizing cultural differences around him or her.

6 Except, of course, in the field of disability, where they are sometimes required to either employ a number of disabled persons or pay a contribution instead of it. 
- The 2nd R stands for respect and explores how the level of respect that one demonstrates regarding those differences.

- The 3rd R stands for reconciliation and explores what is the level of one's competence in reconciling cultural differences.

- The 4th R stands for realization and explores how explores what is the level of one's competence when it comes to realisation of the necessary actions to implement the reconciliation of cultural differences.

The path proposed by Trompenaars and Hampden-Turner (2012) can be viewed as a standard recipe which a company can use to embrace diversity management. Diversity management programs are essentially programs that facilitate change within an organization by changing the beliefs, values, ideologies of the members of the organization when they are faced with workplace diversity (Prasad and Mills, 1997, p. 8). Therefore, diversity management is often discussed in the context of or as being incorporated in those activities of the organization that are related to training and human resources development.

Diversity management policies may, for example, be aimed at ethnic minorities (Copeland, 1988) and provide training that helps to advance ethnic minorities in the organization. The organization may link its core operation systems to managing diversity policies. Thus, for example, it can include a bonus in the reward system that encourages managers to create a working environment which promotes personal growth, assist in the training of staff who belong to ethnic minorities and act as mentors to staff who belongs to ethnic minorities.

Other diversity management policies may, for example, cover measures in the field of senior managerial personnel development that would lead to an increased understanding and visibility of the ethnic diversity of the workforce. These measures promote equitable and fair working environments with high value put on diversity. This training and development efforts of the senior personnel usually result in a new sensitivity towards ethnic, religious or other minorities. This is in turn translated into practical measures, such as accommodating dietary habits and work-free (or holi)days for different ethnic or religious groups.

Research on integration and discrimination of immigrants in Slovenia (Brezigar, 2007a, 2011, 2012a; Bešter and Medvešek, 2010 that has beencarried out in the past decade, provides some interesting insights into this topic and points to an absence of such results in Slovenian workplaces (and consequently, an absence of sensitivity towards ethnic, religious and other minorities).

\section{CULTURAL "ACCOMODATION« IN WORKPLACES IN SLOVENIA}

In the context religious diversity it is a notable fact in Slovenia that believers are not given the right to a leave of absence on the day when they observe religious holidays (Brezigar, 2012a). ${ }^{7}$ One of the largest construction companies that went bankrupt in Slovenia during

7 It needs to be stressed that according to the Slovenian labour law, in practice the employer in Slovenia frequently has the option to decide when an employee can take a leave of absence. The latter applies to all days 
the last economic crisis had an interesting policy on religious diversity ${ }^{8}$ which proved to be successful in dealing with religious festivities. The policy enabled each employee to always take a leave of absence to be able to observe his/her own religious festivities (Brezigar, 2012a).

This kind of flexible arrangement when it comes to religious festivities is more of an exception than a rule in the Slovenian labour market. The common perception in Slovenia is that religion is something that has nothing to do with employment and as such should be regulated separately, without interfering with one's employment obligations (Brezigar, 2011). Let me clarify this statement with another example: observant Muslims are frequently prevented from participating in Friday's prayers due to rigid employment timetables. Most employees in Slovenia have a 30-60 minutes recess for lunch, which includes Fridays on which Muslims observe their weekly prayer in the middle of the day and would therefore require a longer recess.

There is no systemic solution which would accommodate these religious needs which can therefore only be accommodated in agreement with the employer, possibly as part of a diversity management policy. However, such agreements with employers are rare (Brezigar, 2011), and even when they are negotiated, they are not regarded as a company policy on managing diversity, but rather as a nuisance that the company needs to solve in order to keep a valuable employee.

One of the interviewees who was included in the preparation of the Report on Discrimination on grounds of religion and belief in Slovenia (Brezigar, 2011) shared his experience regarding this issue. Most employers dismissed the Friday prayer as a private matter that should not interfere with his employment duties, whereas one of the employers agreed to a longer recess, on the condition that the interviewee promises »not to tell other workers «. Similar approaches aimed at minimizing the issue and solving it without too much publicity have been reported also elsewhere (Brezigar, 2007a; Komac, 2007).

This kind of approach raises two important questions that seem to point to the main issues in the debate on managing diversity in workplaces in Slovenia: firstly, if employees have to hide from other coworkers that their »diversity « has been accomodated, could this be regarded a diversity management policy? And secondly, why should they hide it?

stated in the employment contract but one. In most workplaces (and industries) this rule is not strictly applied. However, it means that if an employer wants to prevent an employee from taking a leave of absence on a determined day (religious festivity; for example, if he employs mostly Muslims and the working process would be stalled should a considerable number of them be absent), he/she can do so. This is an issue especially felt by the Islamic community in Slovenia.

8 This diversity policy has been presented by the CEO of the company at the Conference »Tradicionalni študijski dnevi kadrovskih menedžerjev in strokovnjakov «: Raznolikost: izziv, priložnost, prednost, Terme Ptuj, held on the 15th and 16th November 2007. However, the same company has been exposed by researchers to heavily discriminate against immigrant workers (Brezigar, 2011). 


\section{DIVERSITY POLICY OR LACK OF THEREOF?}

Clearly, if an employer proposes an arrangement that accommodates an employee's »religious « request, and then takes active steps in order to keep other employees from knowing it this cannot be interpreted as an organizational diversity management policy. It's precisely a lack of the latter.

The manager under scrutiny may recognize and respect cultural diversity in this instance, but he is clearly afraid that other employees will not (R)ecognize it and (R)espect it - or if they do, they might perceive his decision as unfair. Since perceptions of unfairness cause employee turnover, low morale and low motivation (Herzberg, 1968), it makes sense for a manager to try to avoid them. But if the majority of the workforce simply won't understand his decision, isn't there an organisation-wide problem of awareness about cultural differences? One that should be dealt with in the first place? We can therefore conclude that in this case the organisation as a whole (and not the manager) does not know how to deal with cultural diversity.

The inability of organisations in Slovenia to cope with cultural diversity has been shown in several studies on integration and discrimination of ethnic minorities (Brezigar, 2007a, 2012a, 2012b): for example, when third country nationals mentioned positive experiences of the Slovenian society's ability to manage diversity, they made it clear that most instances were possible due to the personal initiative of the person (civil servant, teacher, doctor, nurse), and despite the lack of systemic solutions (rather than because of them) (Brezigar, 2012b). When such »illuminated « workers did not cross the paths with the interviewees, the experiences were either predominantly negative or bordered to plain discrimination (Brezigar, 2012b).

These findings also seem to be confirmed by a recent study on diversity management in companies (Kosi, Nastav and Dolenc, 2012). The authors state as follows: "Most large and medium-sized enterprises in Slovenia have not (yet) thought about diversity management. As a consequence, they don't have goals /.../ and a strategy for managing diversity. Since they have not thought about this topic, in most companies interviewees didn't know if it would be necessary [to do something about it, author's note]" (Kosi et al., 2012, p. 87). Most companies in this study have shown a positive attitude towards managing diversity in terms of gender, age and hobbies (in this order of likeability) (Kosi et al., 2012, p. 87). As regards ethnicity or nationality, companies were more reserved and had no distinct opinion (Kosi et al., 2012, p. 87).

Another study Dolenc (2011, p. 81-82) has found that almost all companies agree with the principle of non-discrimination based on ethnicity and race. However, $73 \%$ of the companies included in his study acknowledged that their workforce is diverse, while a third confirmed that they categorise employees also according to national, ethnic and racial affiliation.

These research results cannot be misinterpreted: they clearly suggest that companies neither feel the necessity nor are aware of problems that would call for managing cultural 
diversity, although they acknowledge the existence of such diversity among their workforce. On the other hand, studies on integration and discrimination of ethnic minority members (Brezigar, 2007a, 2012a, 2012b; Bešter and Medvešek, 2010; Komac, 2007) clearly suggest a need for systemic solutions that would accommodate cultural diversity, including managing diversity policies.

So far, we could summarize the status quo as follows: organisations in Slovenia do not systematically address the issue of cultural diversity. Ethnic and religious minorities often complain that such diversity is not being addressed and individual managers or workers find themselves unprepared when faced with it. However, this still does not explain why a manager should hide the fact that he has offered to accommodate religious needs of a co-worker (instead of proposing or implementing a diversity management policy). I will now further examine this issue.

\section{THE FEAR OF EXCEPTIONS}

This conduct of the manager probably originates primarily from a strange combination of lack of skills in the field of managing cultural diversity and rigid application of management principles.

Even a superficial glance at the offer of non-formal training courses for companies on soft skills in Slovenia shows that there is hardly any offer (and therefore probably interest) for trainings that deal with cultural diversity. Trainings on leadership, for example, are stretched to include some kind of training on diversity, such as management of difficult employees or intergenerational differences, but this does not include cultural diversity. Trainings on negotiations grasp the importance of cultural diversity, but are aimed at issues that become relevant when one deals with external audiences, such as suppliers or buyers. Trainings on sales and marketing deal with diversity through focusing on psychological archetypes that can be used to improve one's marketing and sales results. Trainings on effective communication usually deal with diversity among people, but their focus is on »how to communicate «, rather than on »what to do«, and therefore fail to provide an encompassing answer to managing cultural diversity in workplaces.

Given the aforementioned studies and the situation in the training market, it is fairly safe to assume that managers in Slovenian companies lack even the most basic skills or competences required to recognise cultural diversity and act accordingly. In North America, the needs for education and training in diversity management have attracted a number of consultants and other professionals, thus creating a new industry (MacDonald, 1993, in Prasad and Mills, 1997, p. 4), one that reduces managing diversity to video trainings, intercultural workshops, seminars to promote cultural sensitivity, and the like (Allen, 1991; MacDonald, 1993, in Prasad and Mills, 1997, p. 4). ${ }^{9}$ This created a positive connotation

9 One of the fundamental reasons for these developments is the fact that diversity management has originally developed in North America, where the population is extremely skilful in changing any revolutionary ideas or reform movement in commercial and modern products (Roszak, 1969). 
of diversity and linked it with images of cultural hybridity, harmonious co-existence and colorful heterogeneity (Prasad and Mills, 1997, p. 4). In Slovenia, such an industry has not developed and there seems to be no positive connotation related to cultural diversity in workplaces.

Because of this lack of skills companies in Slovenia fail to systemically take advantage of cultural diversity even in its most rudimental forms. For example, an important part of managing diversity policies consists of the »utilizing differences « approach (Liff, 1997, p. 15; cf. Tilker, 2010), according to which differences among social groups are recognised, taken advantage of, and lead to different treatment, rather than positive discrimination policies. An example of this approach in Slovenia could be, for example, to send an Albanian salesman selling door to door to a predominantly Albanian neighbourhood, a Hungarian salesmen to a Hungarian neighbourhood and a Slovenian salesman to a predominantly Slovenian neighbourhood, since the cultural (and linguistic) proximity of the seller and the buyer should result in higher sales. However, in order to conceive such a use of the cultural competences of one's workforce, one needs first to acknowledge the value of cultural diversity - and therefore to have basic competences in cultural sensitivity.

If managers do not possess such skills when they are confronted with cultural diversity, they apply their (mainstream) management skills and either insist on treating all employees equally (pushing, for example, a religious need for a meatless meal or a parent's need for flexible working time to the "private sphere « of the employee), or on making exceptions in such a way that they will not disrupt the functioning of organisation by creating justice-related problems (e.g. by hiding them from the rest of the workforce). In this latter instance, the manager fears that the exception he is going to make will cause dissatisfaction among other workers, who will then feel they are not being treated equally. Since the manager has no basic skills in managing cultural diversity, he or she does not realise that treating »equal things equally « is as important for workplace justice as »treating different things differently «. And even if he or she realises it on the basis of a moral imperative, he or she does not have the skills to convert it to a diversity management policy that will be accepted by his or hers co-workers.

Another fear managers seem to face in this instance is that by making an exception they will start a spiral where everybody will have grounds on which one would want to be treated differently (Brezigar, 2007a, 2012a), and the organisation will not be able to function.

In fact, according to the paradigm of modern management, organisations are regulatory mechanisms governing the organization of time, space and activities (Marsden, 1997). Company rules and standards allow the comparison of the individual performance, actions, conduct and thought with those of other employees and provide penalties when one does not adhere to them (Marsden, 1997). Techniques for managing human resources are the means of observation, investigation and "normalisation" of employees in accordance 
with this standard (Marsden, 1997). Managers therefore fear that allowing too many exceptions and accommodating too many cultural (and other) needs will erode the ability of the organisation to function - namely to set standards that need to be met by all employees and to compare employee performance. Therefore, when managers need to grant an exception, they try to hide it and preserve at least a superficial illusion that they are treating all employees equally.

It is true that diversity managing policies are to a great extent based on the values of diversity and the principle of need, and to a lesser extent aspire to create equality among the workforce. As Marsden (1997) explains, the principles on which modern management is based are incompatible with diversity managing policies that pay attention only to the individual and basically create individual discrimination. Undesirable effects and side effects in the workplace are among the greatest concerns of organizations that introduce diversity managing policies. But it is also true that diversity management policies strive towards adapting the working conditions and working environment to every individual in such a way that the organisation is able to take full advantage of the potential of each worker: not only value diversity, but capitalise on it.

Therefore, managers who prefer to deal with cultural diversity by making an exception and hiding it from the rest of the workforce rather than introducing a diversity management policy, see only half of the picture: they are focused on concerns of equality and comparability, and do not see the opportunities that are being missed because they are not taking advantage of the full potential of each worker - in terms of abilities, skills and knowledge. They perceive cultural diversity as a burden, rather than a value. And they are right insofar as without basic competences and skills they are ill equipped to recognize cultural differences, respect them and consequently utilise them.

\section{CONCLUSIONS}

»When in Rome, understand the behaviour of Romans, and thus become an even more complete Japanese« (Japanese saying, in Trompenaars and Hampden-Turner, 2012, pp. $5-6) .{ }^{10}$

Experiences of the members of ethnic, religious and national minorities in the labour market in Slovenia suggest that a systemic approach towards diversity in organizations is needed. However, organizations in Slovenia do not seem to feel the need to deal with the cultural diversity of their workforce. Moreover, investigations that have been carried out in the past years suggest that the level of competences and skills in this field could be so low that organisations are not able to grasp the advantages that diversity managing policies could bring them and to assess whether they make sense (for them) from an economic point of view.

10 This is a Japanese (bettered) version of Saint Ambrose ‘s »When in Rome, behave as Romans do « - one that implies that you become (a) more complete (Japanese) if you understand the culture of where you are. 
Diversity management policies are rooted in some kind of »complementarily principle«, where different individuals complement each other and create a perfect whole. In contrast, equal opportunity policies, on which most organisations in Slovenia seem to rely, are based on the principle of equality, where $n$ is the number of equal parts that create a perfect whole. But can Slovenian organisations (and above all companies) afford to reject an expansion of the »whole « in a world so competitive and so closely intertwined as ours, where diversity managing policies are only a fraction of the individualisation taking place in companies, merely because they lack the necessary sensitivity and skills?

Managing diversity presupposes that the organization actively recognizes and values the multicultural nature of modern workforce. The basic premise of diversity managing policies is the belief that the traditional monoculture organizations can not operate efficiently if their workforce is ethnically and hence culturally diverse. With processes of globalisation and integration, and increased labour force and migration flows (that need to be added to previous immigration flows, especially in Slovenia), more and more companies are faced with a culturally diverse workforce that only adds to the cultural diversity

More and more companies face mergers and acquisitions or work closely with partners abroad. As they grow larger and develop internationally, they experience more and more pressure to adapt their organisation, product or service to the local characteristics of the market, the legislation and the cultural system. But without basic skills and competencies on managing cultural diversity, their road will be much bumpier than it could be.

\section{REFERENCES}

Bartels, R. (1967). A Model for Ethics in Marketing. Journal of Marketing, 31(1), 20-26.

Bešter, R. (2007). Socialnoekonomska integracija priseljencev iz prostora nekdanje Jugoslavije in njihovih potomcev v Sloveniji. In M. Komac (ed.), Priseljenci (pp. 559-590). Ljubljana: Institute for Ethnic Studies.

Bešter, R. and Medvešek, M. (eds.) (2010). Državljani tretjih držav ali tretjerazredni državljani. Integracija državljanov tretjih držav v Sloveniji. Ljubljana: Institute for Ethnic Studies.

Bloo, G. (1994). Understanding Professional Culture in Organisational Context. Organization Studies, 15(2), 275-295.

Brezigar, S. (2007a). Pojavi etnične diskriminacije v javni upravi, vojski in policiji v RS. In M. Komac (ed.), Priseljenci (pp. 257-301). Ljubljana: Institute for Ethnic Studies.

Brezigar, S. (2007b). Politike za preprečevanje in odpravljanje etnične diskriminacije in njihov vpliv v delovnem okolju. Razprave in gradivo /Treatises and Documents, 53-54, 230-249.

Brezigar, S. (2010). "Dobrodošli v Slovenijo, vendar ne zahtevajte preveč!” Izseki iz življenja državljanov tretjih držav na trgu delovne sile v Republiki Sloveniji. V M. Medvešek in R. Bešter (ur.), Državljani tretjih držav ali tretjerazredni državljani? (pp. 143-171). Ljubljana: INV.

Brezigar, S. (2011). Country report 22011 on the economic case for antidiscrimination, Slovenia. Utrecht: Human European consultancy; Wien: ÖSB consulting GmbH.

Brezigar, S. (2012a). Country report 2 2012, discrimination on the ground of religion or belief, Slovenia. Utrecht: Human European consultancy; Wien: ÖSB consulting GmbH.

Brezigar, S. (2012b). Do third country nationals in Slovenia face prejudice and discrimination? Dve domovini/Two Homelands, 35,149-161. 
Copeland, L. (1988). Valuing diversity, part 2: pioneers and champions of change. Personnel, 65(7), 44-49. Deal, T.E. and Kennedy, A. A. (2000). Corporate culture: The rites and rituals of corporate life. New York: Perseus.

Deal, T.E. and Kennedy, A. A. (2008). The New Corporate cultures. Revitalizing Workplaces after Downsizing, Mergers, and Reengeneering. New York: Perseus.

Dolenc, P. (ed.) (2011). Diskriminacija na trgu dela v Sloveniji. Koper: Fakulteta za management.

Farley, J. E. (1990). Sociology. Carson City: Prentice Hall.

Giddens, A. (2002). Sociology. Cambridge: Polity publishing.

Golja, M. (2007). Tujcem omogočen lažji vstop na slovenski trg dela. Pravna praksa, 45, 20-23.

Golja, M. (2008). Kako pomembna je izobrazba tujca za zaposlitev v Sloveniji? Pravna praksa, 16/17, $21-23$

Greif, T. (2009). Dobre prakse v Sloveniji: upravljanje raznolikosti v zaposlovanju. Ljubljana: Škuc. Pridobljeno s http://www.raznolikost.org/publikacije/prirocnik_dobreprakse.pdf.

Greif, T. (2009a). Upravljanje raznolikosti v zaposlovanju: smernice za delodajalce in sindikate. Ljubljana: Škuc. Pridobljeno s http://www.raznolikost.org/ publikacije/prirocnik-progress.pdf.

Haralambos, M., Holborn, M. and Robin, H. (2006). Sociology: Themes and Perspectives. London: Harper Collins Publishers.

Herzberg, F. (1968). One More Time: How Do You Motivate Employees. Harvard Business Review, 46(1), 53-62.

Hofstede, G. (1980). Culture's consequences: International differences in work-related values. Beverly: Sage.

Hofstede, G. (2002). Dimensions do not exist: A reply to Brendan McSweeney. Human Relations, 55(11), 1355-1361.

Hogan, C. (2002). Understanding faciliation. London: Kogan Page.

Jones, M. (2007). Hofstede - Culturally questionable?, Oxford Business \& Economics Conference. Oxford, UK, 24-26 June, 2007.

Komac, M. and Medvešek, M. (ed.) (2005). Percepcije slovenske integracijske politike. Ljubljana: Institute for Ethnic Studies.

Komac, M. (ed.) (2007). Priseljenci. Ljubljana: Institute for Ethnic Studies.

Kosi, T., Nastav, B. and Dolenc, P. (2012). Upravljanje raznolikosti v slovenskih in tujih podjetjih. Koper: Založba Univerze na Primorskem.

Latour, B. (1993). We Have Never Been Modern. Cambridge: Harvard University Press.

Liff, S. (1997). Two routes to managing diversity: individual differences or social groups characteristics. Employee Relations, 19(1), 11-26.

Marsden, R. (1997). Class Discipline: IR/HR and the Normalization of the Workforce. In P. Prasad, A. J. Mills, M. Elmes and A. Prasad (eds.), Managing the Organizational Melting Pot. Dilemmas of Workplace Diversity. Thousand Oaks, London in New Delhi: Sage.

Mavin, S. and Girling, G. (2000). What is Managing Diversity and Why Does It Matter? Human Resource Development International, 3(4), 419-433.

McSweeney, B. (2002). Hofstede's 'Model of National Cultural Differences and Consequences: A Triumph of Faith - A Failure of Analysis. Human Relations, 55(1), 89-118.

Medica, K. (2010). Sodobni integracijski procesi in kontroverznosti krožnih migracij. In K. Medica, G. Lukič and M. Bufon (eds.), Migranti v Sloveniji - med integracijo in alienacijo, (pp. 37-57). Koper: Univerzitetna založba Annales.

Medica, K., Lukič G. and Bufon, M. (eds.) (2010). Migranti v Sloveniji-med integracijo in alienacijo. Koper: Univerzitetna založba Annales. 
Pajnik, M., Bajt, V. and Herič, S. (2010). Migranti na trgu dela v Sloveniji. Dve domovini /Two Homelands, 34, 111-125.

Prasad, P. and Mills, A. J. (1997). From Showcase to Shadow. Understanding the Dilemmas of Managing Workplace Diversity. In P. Prasad, A. J. Mills, M. Elmes, A. Prasad (eds.), Managing the Organizational Melting Pot. Dilemmas of Workplace Diversity (pp. 3-31). Thousand Oaks, London and New Delhi: Sage.

Roszak, T. (1969). The Making of a Counter Culture: Reflections on the Technocratic Society and Its Youthful Opposition. Garden City, New York: Anchor Books.

Schein, E. H. (2010). Organizational Culture and Leadership. San Francisco: Jossey-Bass.

Schwartz, S. H. (1994). Beyond Individualism/Collectivism: New Cultural Dimensions of Values. In U. Kim, H. C. Triandis, C. Kagitcibasi, S.C. Choi and G. Yoon (eds.), Individualism and Collectivism: Theory, Methods and Applications (pp. 85-119). London: Sage.

Tilker, L. (2010). Managing Diversity: Attaining Competitive Advantage Through Diversity. Retrieved from http://content.spencerstuart.com/sswebsite/pdf/lib/diversity-en.pdf.

Trompenaars, F. and Hampden-Turner, C. (2012). Riding the Waves of Culture: Understanding Diversity in Global Business. London, Boston: Nicolas Brealey Publishing. 